NR 875 PROBLEMY ZARZĄDZANIA, FINANSÓW I MARKETINGU NR 41, t. 12015

DOI: $10.18276 /$ pzfm.2015.41/1-26

JAN KREFT ${ }^{1}$

Uniwersytet Jagielloński

\title{
CRITICAL COMMENTS ON CSR OF MEDIA ORGANISATIONS - BETWEEN MARKETING AND MISSION
}

\begin{abstract}
Summary
Public and commercial media enterprises adopt and communicate their CSR standards. It mainly refers to the largest television and radio broadcasting partnerships. However, in the field of their basic activities, which are namely: providing information, as well as creating and distributing media products, the aims and objectives defined by CSR are actually included in the functions and mission of media. Considering this fact, CSR in media organisations come as a multiplication of basic expectations and obligations of media. For media organisations (public media in particular) accepting and communicating CSR standards means accepting and communicating basic media functions with the consideration of methods and aims characteristic for commercial organisations. It may be interpreted as a form of creating an image which aims at the increase in value.
\end{abstract}

Keywords: CSR, media organisations, image creation, value of organization

\section{Introduction}

The concept of corporate social responsibility (CSR) has been formed on the basis of a belief stating that business organisations shall operate in a responsible way, and they do not aim only at economic targets. Media organisations also announce their adoption of the CSR standards. However, the need of their acceptance is questionable, considering basic social functions, aims and missions of media and perceiving media as "social good." In this case, acknowledgement and implementation of the CSR concept may be understood as a marketing measure which is supposed to increase the market value of a media organisation.

\footnotetext{
${ }^{1}$ jan.kreft@uj.edu.pl.
} 


\section{Literature review}

The CSR concept has been formed on the basis of a belief that business organisations shall operate in a responsible way. Although deviations from such a general principle are emphasized, ${ }^{2}$ the popularity and development of the CSR idea strengthens a commonly shared belief that business organisations do not only pursue economic aims, but their operations are ruled by three imperatives: economic, social and environmental. ${ }^{3}$ Supporting CSR is supposed to make us realise how the consideration of social or environmental concerns affect the financial situation of an organization. ${ }^{4}$

The most frequently cited definitions of CSR emphasize the concern about the influence of all corporate operations on social welfare. ${ }^{5}$ CSR means "involvement of business into ethical operations and participation in the economic development, demonstration of respect for people, local communities, nations and environment. CSR combines concepts of global citizenship with environmental concerns and sustainable development." ${ }^{16}$ In practice, it means informing about business operations in annual reports, publications, participating in socially-oriented promotional campaigns, charity or cooperation with non-governmental organisations. In this way, CSR comes as a method of interaction between corporate authorities and the society, aiming at the formation of external images about the organization. ${ }^{7}$ The recipients of information communicating social responsibility are stakeholders, namely: shareholders (current and potential), employees, customers, media and authorities. The CSR features are assumed to be honesty, transparency, open-minded authorities and higher social and environmental standards.

A relatively new phenomenon is CSR institutionalization, which is manifested by trainings for specialists on CSR implementation, CSR reports, trainings

${ }^{2}$ D. Matten, J. Moon, Implicit and Explicit. CSR: a conceptual framework for a comparative understanding of corporate social responsibility, "Academy of Management Review" 2008, Vol. 33, No. 2, p. 404-442.

${ }^{3}$ W. Norman, C. MacDonald, Getting to the bottom of "Triple Bottom Line", "Business Ethics Quarterly" 2004, Vol. 14, No. 2, p. 243-262.

${ }^{4}$ M.E. Porter, M.R. Kramer, Strategy \& society: the link between competitive advantage and corporate social responsibility, "Harvard Business Review" 2006, Vol. 84, No. 12, p. 78-92.

${ }^{5}$ A. Dahlsrud, How corporate social responsibility is defined: an analysis of 37 definitions, "Corporate social responsibility and environmental management" 2008, Vol. 15, No. 1, p. 1-13.

${ }^{6}$ M. Rybak, Spoleczna odpowiedzialność biznesu - idea i rzeczywistość, „Gospodarka Narodowa" 2001, Vol. 3, No. 28, p. 18.

${ }^{7} \mathrm{C}$. Deegan, The legitimising effect of social and environmental disclosures $-a$ theoretical foundation, "Accounting, Auditing and Accountability Journal" 2002, Vol. 15, No. 3, p. 292. 
on ISO 14001 implementation and academic programmes/courses dedicated to CSR.

\section{Research problem}

The article presents the following research thesis and three hypotheses. ${ }^{8}$ The thesis is: Media enterprises are exceptional organisations in terms of their (their products) social impact.

The thesis formulated above indicates the main objective of the article, namely: the analysis of the need of implementation and communication of CSR by media organisations in the context of the social functions they perform and their social mission.

This thesis is followed by the subsequent hypotheses:

The main hypothesis (H1): Implementation and communication of CSR in media

organisations have a diversified use (considering their basic division into commercial and public media) and are elements of marketing activities.

$\mathrm{H} 2$ : In the field of media programmes, the implementation of CSR in media enterprises comes as a duplication of media responsibility which results from their social impact.

H3: In public media enterprises CSR means the same thing as so called the public mission which they perform.

\section{Applied research methods}

In the article the methods of logical analysis have been applied, including deduction in particular. Also, the method of direct observation has been used (the author participated in management processes carried out by the executives in three media corporations; the author also managed one of a larger Polish media organisation for eight years) as well as the method of indirect observation (the documentation method).

The analysis of the collected research material - mainly reports and information on CSR presented by the main Polish broadcasting TV and radio stations and organisations which provide analyses concerning CSR in media - has been subordinated to a general analytical concept. The explanation of the material de-

\footnotetext{
${ }^{8}$ J. Kreft, Zagrożenia zwiazane ze schyłkiem tradycyjnych mediów, in: Media publiczne wobec wyzwań wspótczesnego świata, Kancelaria Senatu. Biuro analiz i dokumentacji, Opinie i Ekspertyzy OE - 220, Warszawa, July 2014, p. 95.
} 
pended on the research hypotheses. In accordance with R.K. Yin's methodological indication, the author focuses on the key variables, omitting other data at the same time. ${ }^{9}$

\section{Critical comments on CSR}

There is a lot of criticism of social responsibility of business organisations in literature, and its most known example may be M. Friedman's attitude, presented in an article published by „New York Times”. He stated that enterprises do not aim at solving social problems. ${ }^{10}$ Economic entities have neither political nor economic legitimation to do so, but first of all such an activity could hinder them from obtaining their basic target, that is namely: profit maximisation. "The doctrine of social responsibility (...) is generally subversive ... there is one and only one business responsibility - using resources and involving them into operations which contribute to profit maximisation." Moreover, people can be responsible or irresponsible (ethical or unethical) - not business.

Therefore, corporate social responsibility appears to be "a false virtue" which contributes to the weakening of market economy, and it is "an aberration of a part of business". ${ }^{11}$ Organisations, which have not been democratically elected, shape public opinion and promote concepts of corporate social responsibility. This, in fact, is a mixture of anti-business, anti-capitalistic and anti-globalisation practices. Moreover, managers do not have any mandate to decide which social problems are to be solved and in what way. They are also not prepared to do this in any substantive way.

E. Elhague criticizes the acknowledgement of CSR in an equally principled way, however from a different point of view. He states that among various, commonly mentioned types of activity included in this term, we should pay attention only to these which are really connected with the acceptance of a decrease in profit expressed by the owners and management staff. ${ }^{12}$ If a media partnership decides to resign from some of its profits for CSR activities, then such activities become an example of social responsibility. Considering such a context, the approach presented by some broadcasting stations seems to be ambiguous - for in-

\footnotetext{
${ }^{9}$ R.K. Yin, Case study research: design and methods, Sage Publications, Beverly Hills 1994, p. 109.

${ }^{10} \mathrm{M}$. Friedman, The social responsibility of business is to increase its profits, New York Times 1970.

${ }^{11}$ D. Henderson, Misguided virtue: false notions of corporate social responsibility, Hobart Paper, 2001, p. 142.

12 E. Elhague, Corporate managers' operational discretion to sacrifice corporate profits in the public interest, in: Environmental protection and the social responsibility of firms, eds. L.B. Hay, R.N. Stavins, R.K. Vietor, RFF Press, Washington 2005, p. 13-76.
} 
stance, some examples of social responsibility could be some TV stations appealing to their viewers for money collected for a foundation which is affiliated with these TV stations (TVN and Polsat). In these cases CSR is persistently and groundlessly identified with philanthropy.

An overriding factor of CSR acceptance is supposed to be the sense of responsibility for social environment in all its significant dimensions. Numerous research studies on motives let us arrive at the conclusions stating that applying CSR has been limited to some cases in which the owners expect managers not to treat profits as a target which must be obtained at any price by any measures. In other words, external pressure is the main factor which contributes to the acceptance of CSR. It is connected with a number of other factors, such as:

- product and service commodisation,

- retaining current customers' loyalty,

- increase in the customers' market awareness/market orientation,

- consumerism, a civil and institutional movement aiming at the increase in consumers' rights and representation in relation to sellers,

- pressure and expectations of non-governmental organisations.

\section{Specific character of media organisations}

The specific character of media organisations results from their social role and their responsibility which is usually referred to the respect for freedom of publication, to any damages incurred by individuals and society in connection with a particular publication and to any positive (not only negative) aspects of such a publication. In a definition formulated by D McQuail, such responsibility refers to "any voluntary or non-voluntary processes in which media are responsible for the quality and/or consequences of a publication in front of their users." 13 It therefore refers first of all to the impact of media and media products.

Such impact is connected with a model which presents media as a social good. In this model citizens "designate" media to the particular individuals in the act of confidence - this idea is close to the trust concept. ${ }^{14}$ This social servitude is expressed, for example, in a concept of public media "mission."

This general specificity - common for all media - is followed by public media specificity. Public media in Poland have the form of a sole shareholder company of the State Treasury.

\footnotetext{
${ }^{13}$ D. McQuail, Media accountability and freedom of publication, Oxford University Press, Oxford 2003, p. 14-15.

${ }^{14}$ J. Kreft, Za fasadą społeczności, Wyd. Uniwersytetu Jagiellońskiego, Kraków 2015, p. 28.
} 
The specific character of media organisations results also from the social functions which they perform, including the following: ${ }^{15}$

1. Observation of environment - media observe and report significant changes of natural environment. "Significant" means those which may be hazardous or may come as a threat to people, institutions or the whole society.

2. Correlation of reaction to environment - media provide operational patterns to individuals, communities and institutions. It is supposed to prevent hazards and to take advantage of opportunities. Media also support models of social organisations and at the same time they support social balance and stability.

3. Heritage transmission - media convey the most important elements of our heritage, especially those connected with overcoming threats and taking advantage of opportunities. They also communicate behavioural patterns which fully define the identity of individuals and communities. In this way they affect the social structure (educational and social functions).

The fourth, entertainment function has been added by $\mathrm{Ch}$. Wright. It can be defined as reducing social tension, as Ch. Wright noticed. ${ }^{16}$

In the Polish media system, the essential significance is attained to the fact that media organisations simultaneously perform two functions: commercial and social mission. ${ }^{17}$ As commercial law partnerships, commercial (and also public service) media are focused on gaining profits. In the case of public media, their founding body is the Minister of the State Treasury, however, their operation is regulated by the Broadcasting Act which defines the social interest/public media mission. The specific character of media organisation can be also observed in legal conditions defined in "the public media mission" which, in practice, is supposed to mean offering "various programmes and other services concerning information, editorial commentaries, culture, entertainment, education and sport to the whole society and its particular groups. These services shall be characterised by pluralism, neutrality, balance, independence, innovation and integration of the message". ${ }^{18}$

The art. 21 of the Broadcasting Act mentions "being responsible for the message, honest presentation of the whole variety of events and phenomena taking

\footnotetext{
${ }^{15}$ M. Mrozowski, Media masowe. Władza, rozrywka i biznes, Oficyna Wyd. ASPRA - JR, Warszawa 2001, p. 113-114.

${ }^{16}$ C.R. Wright, Mass communications. A sociological perspective, Radon Mouse, New York 1969, p. 14.

${ }^{17}$ R.G. Picard, Media economics. Concepts and issues, Sage Publications, Newsbury Park - New Delhi, London 1989, p. 14.

${ }^{18}$ J. Kreft, Zagrożenia zwiąane ze schytkiem..., p. 95.
} 
place in the country and abroad, supporting free development of citizens' opinions and forming public opinion, providing citizens and their organisations with an opportunity to participate in public life by presenting various views and attitudes, and exercising the right to control and to express social criticism, and also supporting cultural, scientific and educational development with special consideration of Polish intellectual and artistic achievements." ${ }^{19}$

\section{CSR in media enterprises}

CSR activities of media companies often come as a subject of various analyses performed by different monitoring organisations. The holistic approach toward CSR as to an element of the corporate strategy can be found in reports presented by the CSRHUB, the largest organisation which provides analysis and evaluation of corporate social responsibility, including media corporations as well. ${ }^{20}$ The organisation applies such an analytical tool as a ranking, which includes the following categories: community (human rights, safety and quality of products, philanthropy), community development (relations between an organisation and the community/communities it operates in and employees' voluntary service), products (responsibility for the design, management of products and services and their impact on consumers), employment issues (for example, the efficiency of employment programmes, employees' loyalty, social relations and respect for employees' rights), natural environment protection, management of resources, quality of management (including respect for ethical rules presented by the leaders and transparency of operation).

In Europe some similar analyses are performed, among other organisations, by Media CSR Forum. It is a British organisation which has been operating for over 10 years. It promotes the sustainable development of media, including BBC first of all. In its analyses, it particularly considers the following elements which are specific for this sector:

- responsibility for published information/pictures of particularly drastic character, which may be harmful for feelings of society members,

- protection of minors' privacy,

- media responsibility for broadcast advertisement,

- promotion of advertisement which encourages people to sustainable consumption,

\footnotetext{
${ }^{19}$ The Broadcasting Act dated on 29th Dec.1992, Journal of Law No. 04.253.2531 with later amendments.

${ }^{20}$ CSRHub schema description, www.csrhub.com/content/csrhub-data-schema/ (5.03.2015).
} 
- obligation of education and information,

- media responsibility for any possible consequences of broadcast/published media contents,

- transparency referring to the editorial part (separating information from comments and opinions,

- interference of the media organisation owners into editorial content,

- protection of privacy,

- providing balance between the right of the society to be informed and the right of individual society members to have their privacy protected.

On the Polish media market all the leading media enterprises communicate their implementation of CSR.

Public television identifies it with the public mission it performs. Additionally, in the case of TVP SA, in the principles concerning the realisation of the public mission adopted in 2005, the obligations toward public institutions and social organisations are particularly emphasized. In accordance with the Ordinance of the National Broadcasting Council from 2011, public benefit organisations may apply for the broadcasting of spots concerning social campaigns free of charge - they are verified by Social Campaign Committee (constituted by TVP and the Council of Public Benefit Organisations).

A similar point of view is presented by public radio stations, but only few of them communicate their CSR activities (for example, Polskie Radio Zachód)

As regards commercial media, in the conditions of oligopoly which rules the TV market, three leading partnerships communicate their CSR activities, however, stressing them in a different way. TVN SA assumed the strategy of social responsibility in 2013. It refers to the most important stakeholders, and it is divided into the following components:

- social involvement (TVN "Nie jesteś sam" [You are not alone] Foundation),

- viewers ("we continue a dialogue with our audience", "we provide honest information and we pay attention to important social issues").

An example of CSR initiatives in TVN can be Kontakt24 (a service to exchange information among people in which it is possible to create one's own multimedia website"). The service promotes the idea of citizen journalism. Another example given by TVN is the operation of TVN "Nie jesteś sam" [You are not alone] Foundation, a social initiative "Lekarze ratują życie" [Doctors save life] and an internship programme dedicated to students "TVN Poławiacze Perel" [TVN Pearl Fishers]. 
Polsat Television informs about its CSR initiatives giving the example of Polsat Foundation. Polsat Cyfrowy (Digital Polsat) communicates "the CSR philosophy" which should be understood as "activities realised in the field of social responsibility" including: improvement of relations with the market and customers, activities which positively affect natural environment, activities supporting the development of an attractive place of work, and those which guarantee an open dialogue with the society ${ }^{21}$.

\section{Conclusions}

The critical approach to CSR in media organisations results from two sources:

- CSR is generally inadequate to all business organisations,

- CSR copies their social functions and the role they assume in the society. It is an immanent feature of the functioning of a media organisation in its basic dimension.

As presented above, the attempt of defining specific elements which let us perform an analysis of the progress concerning the "advancement" level of a media organisation, drives us to the conclusions stating that - in the context of such activities of media enterprises as orders (relations with commercial contractors, internal employment policy, etc.) - communication and implementation of CSR standards seem natural. However, it only proves the expectations towards media organisations which are particularly connected with maintaining journalistic standards.

Commercial media organisations are the main group involved in the communication and implementation of CSR. The question of multiplying the theme of social responsibility of media refers first of all to public media. In this case, implementation of CSR and information about this fact actually come as a duplication of statutory requirements, a secondary reassurance that a particular company obeys the law.

CSR comes as the consequence of the presence of media enterprises on the market first of all. There the companies compete with each other for recipients' attention and advertising income. The consumer-investor dimension of media activities also contributes to the increase in the value of a media organisation through the improvement of its image of a producer of goods and services.

21 Nasza filozofia CSR, www.grupapolsat.pl/pl/odpowiedzialny-biznes/nasza-filozofia-csr (11.04.2015) 
Considering the present situation, the main hypothesis stating that CSR has various applications in media organisations (with the consideration of their basic division into commercial and public media) has been proved as well as the fact that it is an element of marketing activity. Adopting and communicating CSR by media companies in this (basic) part of their operations which concern preparation and distribution of media contents, can be interpreted as superficial activities which aim first of all at the improvement of media image.

\section{Bibliography}

CSRHub schema description, www.csrhub.com/content/csrhub-data-schema/.

Dahlsrud A. How corporate social responsibility is defined: an analysis of 37 definitions, "Corporate social responsibility and environmental management" 2008, Vol. 15, No. 1.

Deegan C., The legitimising effect of social and environmental disclosures - a theoretical foundation, "Accounting, Auditing and Accountability Journal" 2002, Vol. 15, No. 3.

Elhague E., Corporate managers' operational discretion to sacrifice corporate profits in the public interest, in: Environmental protection and the social responsibility of firms, eds. B.L. Hay, R.N. Stavins, R.K. Vietor, RFF Press, Washington 2005.

Friedman M., The social responsibility of business is to increase its profits, New York Times 1970.

Henderson D., Misguided Virtue: False notions of corporate social responsibility, Hobart Paper 2001.

Kreft J., Za fasada społeczności, Wyd. Uniwersytetu Jagiellońskiego, Kraków 2015.

Kreft J., Zagrożenia zwiazane ze schytkiem tradycyjnych mediów, in: Media publiczne wobec wyzwań współczesnego świata, Kancelaria Senatu. Biuro analiz i dokumentacji, Opinie i Ekspertyzy OE - 220, Warszawa, lipiec 2014.

Matten D., Moon J., Implicit and explicit. CSR: A conceptual framework for a comparative understanding of corporate social responsibility, "Academy of Management Review" 2008, Vol. 33, No. 2.

McQuail D., Media accountability and freedom of publication, Oxford University Press, Oxford 2003

Mrozowski M., Media masowe. Władza, rozrywka i biznes, Oficyna Wyd. ASPRA - JR, Warszawa 2001.

Nasza filozofia CSR, www.grupapolsat.pl/pl/odpowiedzialny-biznes/nasza-filozofia-csr.

Norman W., MacDonald C., Getting to the bottom of "Triple Bottom Line", "Business Ethics Quarterly" 2014, Vol. 14, No. 2.

Picard R.G., Media economics. Concepts and issues, Sage Publications, Newsbury Park - New Delhi, London 1989.

Porter M.E., Kramer M.R., Strategy \& society: the link between competitive advantage and corporate social responsibility, "Harvard Business Review" 2006, Vol. 84, No. 12.

Rybak M., Społeczna odpowiedzialność biznesu - idea i rzeczywistość, "Gospodarka Narodowa" 2001, Vol. 3, No. 28.

The Broadcasting Act dated on 29th Dec.1992, Journal of Laws No. 04.253.2531 with later amendments.

Wright C.R., Mass communications. A sociological perspective, Radon Mouse, New York 1969. 
Yin R.K., Case study research: design and methods, Sage Publications, Beverly Hills 1994.

\title{
KRYTYCZNIE O CSR ORGANIZACJI MEDIALNYCH - MIĘDZY MARKETINGIEM A MISJA
}

\begin{abstract}
Streszczenie
Zarówno publiczne, jak i komercyjne podmioty medialne przyjmują i komunikują standardy CSR - dotyczy to największych spółek telewizji i radia. W sferze podstawowych ich aktywności dostarczania informacji, tworzenia i dystrybucji produktów medialnych, cele i zadania opisywane przez CSR są jednak w istocie ujęte przez funkcje i misję mediów. CSR w organizacjach medialnych jest w tym zakresie powieleniem podstawowych oczekiwań i zobowiązań mediów. Przyjmowanie i komunikowanie standardów CSR jest zatem w przypadku organizacji medialnych (zwłaszcza publicznych) przyjmowaniem i komunikowaniem podstawowych funkcji mediów, ale w sposób i w celu charakterystycznym dla podmiotów komercyjnych. Może być interpretowane jako forma kształtowania wizerunku mająca na celu wzrost wartości organizacji medialnych.
\end{abstract}

Słowa kluczowe: CSR, organizacja medialne, kreowanie wizerunku, wartość organizacji

Thumaczenie: Jan Kreft 
